\title{
Pediococcus pentosaceus as probiotic with cholesterol-lowering ability
}

\author{
Dela Silvia ${ }^{1}$, Lilis Nuraida ${ }^{2,3}$ and Anja Meryandini ${ }^{4,5 *}$ \\ ${ }^{1}$ Postgraduate of Microbiology Study Program, Department of Biology, Faculty of Mathematics and Natural Science, IPB \\ University, 16680, Dramaga, Bogor, Indonesia. \\ ${ }^{2}$ Department of Food Science and Technology, Faculty of Agricultural Engineering and Technology, IPB University, \\ 16680, Dramaga, Bogor, Indonesia. \\ ${ }^{3}$ Southeast Asian Food and Agricultural Science and Technology (SEAFAST) Center, IPB University, 16680, Dramaga, \\ Bogor, Indonesia \\ ${ }^{4}$ Department of Biology, Faculty of Mathematics and Natural Science, IPB University, 16680, Dramaga, Bogor, \\ Indonesia. \\ ${ }^{5}$ Research Center for Bioresources and Biotechnology (RCBIO), IPB University, 16680, Dramaga, Bogor, Indonesia. \\ Email: ameryandini@apps.ipb.ac.id
}

Received 2 December 2019; Received in revised form 27 February 2020; Accepted 24 June 2020

\begin{abstract}
Aims: Hypercholesterolemia which is an elevated blood cholesterol level that considered as a major risk factor for cardiovascular disease, which is the leading cause of death in many countries. Therefore, lowering the cholesterol level is important to prevent the disease. Lactic acid bacteria (LAB) group are often used as probiotics for their healthpromotion which include cholesterol-lowering effect. The purpose of this study was to evaluate the potency of Pediococcus pentosaceus as probiotic that could reduce cholesterol.

Methodology and results: All $P$. pentosaceus strains were able to survive in acid conditions and in the presence of $0.3 \%$ bile salts. These strains had antimicrobial activity against Escherichia coli ATCC 25922, Staphylococcus aureus ATCC 25923, and Salmonella typhimurium ATCC 14028. The LAB were also sensitive to chloramphenicol and showed autoaggregation and coaggregation ability. Pediococcus pentosaceus E5, E7, and E8 were able to remove cholesterol with the highest activity showed by $P$. pentosaceus E7 $(49.00 \pm 2.83 \%)$. Dead cells and resting cells of $P$. pentosaceus $\mathrm{E} 5, \mathrm{E} 7$, and E8 (6-22\%) also able to reduce the cholesterol but not as effectively as growing cells. Cholesterol lowering is often associated with bile salt hydrolase (BSH) enzyme activity, however none of the isolates were found BSH positive in this study.
\end{abstract}

Conclusion, significance and impact of study: The present study suggests that $P$. pentosaceus $\mathrm{E} 7$ has beneficial probiotic properties which can be exploited for probiotic product with cholesterol-lowering effect.

Keywords: Pediococcus pentosaceus, probiotics, cholesterol-lowering

\section{INTRODUCTION}

Cholesterol is an important structural component of animal cell membrane. However, elevated cholesterol levels is a major risk factor for coronary heart disease (Anila et al., 2016). Cardiovascular disease is the leading cause of death for million people worldwide. The risk of developing cardiovascular disease is reduced by $2-3 \%$ when cholesterol level is reduced by $1 \%$ (Alba et al., 2018). Although drugs such as statins, effectively decrease cholesterol level but its side effects are commonly reported (Miremadi et al., 2014). Myalgia is the most common side effect from statin use with rates $1-10 \%$ of patients (Ramkumar et al., 2016).
It has been proposed that consumption of probiotics products able to lower the serum cholesterol level. Probiotics are defined as viable microorganisms that exerts various beneficial effects to the host when ingested in an appropriate concentration. Therefore, the interest in using probiotics to reduce cholesterol level has increased from the last few decades (Anila et al., 2016). Probiotic bacteria mainly belonging to lactic acid bacteria (LAB) included Lactobacillus and Pediococcus. LAB are often used as probiotics for their health-promotion such as lowering-cholesterol, a series of in vitro tests must be applied as the selection criteria to identify potential probiotics.

The results from previous studies showed Pediococcus pentosaceus VJ56 from Idly batter was able 
to reduce 63\% cholesterol (Vidhyasagar and Jeevaratnam, 2013); Lactobacillus plantarum EM from kimchi was able to reduced $80.69 \%$ cholesterol (Choi and Chang., 2015); $P$. pentosaceus from fermented finger millet was able to reduce $34 \%$ cholesterol (Damodharan et al., 2015) and $P$. pentosaceus from breast milk was able to reduce the cholesterol for $15.76 \%$ (Nuraida et al., 2011). Several possible mechanisms for cholesterol removal by probiotics included cholesterol assimilation, adhesion of cholesterol to the cell membrane, conversion of cholesterol to coprostanol, and enzymatic deconjugation of bile salts (Tok and Aslim, 2010).

Hamida et al. (2015) had selected three strains of $P$. pentosaceus from spontaneous fermented corn as a probiotic candidate for chicken. However, this isolate has not been evaluated for its specific functional benefit and probiotic properties for human. Therefore, this study aimed to evaluate the potential of $P$. pentosaceus which isolated from spontaneous fermented corn as probiotics with cholesterol-lowering ability.

\section{MATERIALS AND METHODS}

\section{Sources of microbes}

Lactic acid bacteria (LAB) of Pediococcus pentosaceus $\mathrm{E} 5, P$. pentosaceus $\mathrm{E} 7, P$. pentosaceus $\mathrm{E} 8$ were isolated previously from spontaneous fermented corn and examined previously by Hamida et al. (2015). Pathogenic bacteria (Escherichia coli ATCC 25922, Staphylococcus aureus ATCC 25923, Salmonella typhimurium ATCC 14028) were obtained from Animal Biotechnology and Biomedical Laboratory, RCBIO, IPB University, Indonesia. While, Lactobacillus rhamnosus R23 which used as reference strain for cholesterol lowering was obtained from SEAFAST Center Laboratory, IPB University, Indonesia. All the LAB were grown in the Mann Rogosa Sharpe (MRS) broth media (Merck), while pathogenic bacteria were grown in the nutrient broth (NB) media.

\section{Acid tolerance test}

A low $\mathrm{pH}$ tolerance test was carried out based on Manini et al. (2016). MRSB was adjusted to $\mathrm{pH} 2$ using 37\% hydrochloric acid $(\mathrm{HCl})$ and inoculated with $1 \%\left(10^{7}-10^{8}\right.$ $\mathrm{CFU} / \mathrm{mL}$ ) LAB culture for $2 \mathrm{~h}$ and incubated at $37^{\circ} \mathrm{C}$. The total amount of $L A B$ was determined by the plate count method on MRS agar and incubated for $48 \mathrm{~h}$ at $37^{\circ} \mathrm{C}$. LAB survival rate was determined by the following equation:

$$
\begin{aligned}
& \text { Survival }(\%)= \\
& \frac{\text { Log CFU of viable cells survived }}{\text { Log CFU of initial viable cells inoculated }} \times 100
\end{aligned}
$$

\section{Bile salt tolerance test}

Bile salt tolerance was carried out based on Tokatli et al. (2015). MRS broth containing $0.3 \%(\mathrm{w} / \mathrm{v})$ bile salt
(HIMEDIA) was inoculated with $1 \%\left(10^{7}-10^{8} \mathrm{CFU} / \mathrm{mL}\right)$ $\mathrm{LAB}$ culture and incubated for $6 \mathrm{~h}$ at $37^{\circ} \mathrm{C}$. Then, the total amount of $L A B$ was determined by the plate count method on MRS agar after incubated for $48 \mathrm{~h}$ at $37^{\circ} \mathrm{C}$.

\section{Antimicrobial activity assays}

Antimicrobial activity was evaluated based on Shukla and Goyal (2014) and Wang et al. (2016). Briefly, the tested pathogenic bacteria (E. coli ATCC 25922, S. aureus ATCC 25923 and S. typhimurium ATCC 14028) were grown in NB medium and LAB was grown in MRS broth at $37^{\circ} \mathrm{C}$ for $24 \mathrm{~h}$. Then, the LAB culture was removed by centrifugation at $6000 \times \mathrm{g}, 4^{\circ} \mathrm{C}$ for $10 \mathrm{~min}$. The Petri dishes containing nutrient agar were prepared, previously inoculated with $200 \mu \mathrm{L}$ the tested pathogenic bacteria. After the agar plates had been surface dried, sterilized paper disks were placed aseptically on the agar surface, then $20 \mu \mathrm{L}$ CFS (cell-free supernatant) of LAB were applied to each disk. In another set of experiment, CFS was neutralized to $\mathrm{pH} 6.5$ by $2 \mathrm{~N}$ sodium hydroxide $(\mathrm{NaOH})$, then $20 \mu \mathrm{L}$ of CFS were applied to each disk. The plates were incubated at $37^{\circ} \mathrm{C}$ for $24 \mathrm{~h}$ and the zone of inhibition $(\mathrm{mm})$ was measured and data interpretation referred to Zommiti et al. (2018).

\section{Autoaggregation and coaggregation ability test}

Autoaggregation and coaggregation ability tests were performed based on Seddik et al. (2017) and Ladha and Jeevaratnam (2018). LAB strains were grown for $24 \mathrm{~h}$ at $37{ }^{\circ} \mathrm{C}$ in MRS broth. After centrifugation $(8000 \times \mathrm{g}, 10$ $\mathrm{min}$ ), the cells pellet were washed twice with $0.01 \mathrm{M}, \mathrm{pH}$ 7.2 phosphate buffer saline (PBS) and resuspended in PBS. Then, cell suspensions were mixed by vortexing and autoaggregation was determined after incubation at $37^{\circ} \mathrm{C}$ for $2 \mathrm{~h}$ and $4 \mathrm{~h}$, respectively. Subsequently, an aliquot of these suspensions was carefully removed from the upper layer of the suspension and its absorbance was read at $600 \mathrm{~nm}$ using spectrophotometer. The percentage of autoaggregation was calculated using the formula:

Autoaggregation $(\%)=1-\left(\left(\frac{A t}{A O}\right) \times 100\right)$

where $A t$ represents absorbance value at time $\mathrm{t}=2 \mathrm{~h}$ or 4 $\mathrm{h}$ and $A O$ represents absorbance value at $\mathrm{t}=0 \mathrm{~h}$.

Culture preparation for coaggregation test was carried out as previously described, $2 \mathrm{~mL}$ of LAB culture and 2 $\mathrm{mL}$ of pathogenic culture were mixed, then incubated at $37^{\circ} \mathrm{C}$ for $2 \mathrm{~h}$ and $4 \mathrm{~h}$. Subsequently, an aliquot of these suspensions was carefully removed, and its absorbance was read at $600 \mathrm{~nm}$ using spectrophotometer. The percentage of coaggregation was calculated using the formula:

Coaggregation $(\%)=\left(\frac{A x+A y}{2}\right)-A(x+y) /\left(\frac{A x+A y}{2}\right) \times 100$ 
where $A x$ represents absorbance value of $\mathrm{LAB}$ culture; $A y$ represents absorbance value of pathogenic culture; $A(x+$ y) represents absorbance value of the mixture suspension.

\section{Antibiotic susceptibility}

The antibiotic susceptibility of $P$. pentosaceus E5, E7, and E8 were examined according to Lee et al. (2016) and llavenil et al. (2016). The strains were tested for their susceptibilities against streptomycin $(25 \mu \mathrm{g})$, kanamycin $(30 \mu \mathrm{g})$, chloramphenicol $(30 \mu \mathrm{g})$ and ampicillin $(25 \mu \mathrm{g})$. The Petri dishes containing MRS agar were prepared, previously inoculated with $200 \mu \mathrm{L}\left(10^{7}-10^{8} \mathrm{CFU} / \mathrm{mL}\right) \mathrm{LAB}$ culture. After the agar plates had been surface dried, sterilized paper disks were placed aseptically on the agar surface, then $20 \mu \mathrm{L}$ of antibiotics solution which had been filter sterilized with $0.22 \mu \mathrm{m}$ membrane filter were applied to each disk. After $24 \mathrm{~h}$ of incubation at $37^{\circ} \mathrm{C}$, the diameters of inhibition zone $(\mathrm{mm})$ were measured and data interpretation referred to Shukla and Goyal (2014).

\section{Cholesterol removal by growing cells}

The ability of $L A B$ to reduce cholesterol was analyzed according to Shehata et al. (2016). In short, $1 \%\left(10^{7}-10^{8}\right.$ $\mathrm{CFU} / \mathrm{mL}$ ) of $\mathrm{LAB}$ cells grown overnight were inoculated into MRS broth supplemented with $0.3 \%(\mathrm{w} / \mathrm{v})$ bile salt and $100 \mu \mathrm{g} / \mathrm{mL}$ of water-soluble cholesterol (PEG600, Sigma-Aldrich) which had been filter sterilized with 0.45 $\mu \mathrm{m}$ membrane filter and incubated for $24 \mathrm{~h}$ at $37^{\circ} \mathrm{C}$. Following incubation, the remaining cholesterol concentration of broth was determined. The cells were harvested by centrifugation $(7000 \times \mathrm{g}, 15 \mathrm{~min})$ and $1 \mathrm{~mL}$ of CFS was added to $1 \mathrm{~mL}$ of $33 \%(\mathrm{w} / \mathrm{v})$ potassium hydroxide $(\mathrm{KOH})$ and $2 \mathrm{~mL}$ of absolute ethanol. The mixture was shaken well for $1 \mathrm{~min}$ and then heated for 10 min at $60{ }^{\circ} \mathrm{C}$ water bath. After cooling, $3 \mathrm{~mL}$ of hexane and $2 \mathrm{~mL}$ of distillate water were added then mixed. The mixture was incubated at room temperature $\left(28^{\circ} \mathrm{C}\right)$ for 10 min for phase separation, after which $1 \mathrm{~mL}$ of a separated hexane layer was transferred into clean tube which was then evaporated using a nitrogen stream. Subsequently, 2 $\mathrm{mL}$ of $o$-phthalaldehyde (Sigma-Aldrich) was added, mixed, and stand at room temperature for $10 \mathrm{~min}$. Following the addition of $2 \mathrm{~mL}$ of concentrated sulfuric acid and incubation for $10 \mathrm{~min}$, the absorbance at $550 \mathrm{~nm}$ was read using a spectrophotometer. The cholesterol removal percentage was obtained by comparing the absorbance value with the control (cholesterol standard) as formula below (Ooi and Liong, 2010).

Cholesterol removal (\%)

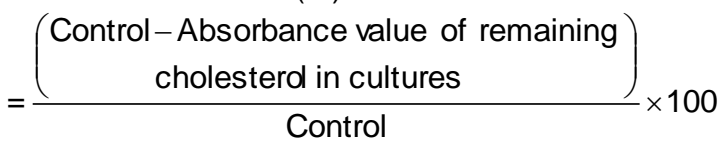

\section{Cholesterol removal by dead and resting cells}

Cholesterol removal by dead and resting cells was determined according to Choi and Chang (2015). LAB was grown for $24 \mathrm{~h}$ in MRS broth, after centrifugation $(7000 \times g, 15 \mathrm{~min})$ cell pellet were washed using steriledistilled water. For cholesterol removal by resting cells, the cell pellet was suspended in $0.05 \mathrm{M}$ PBS $(\mathrm{pH} 7.2)$ containing $0.3 \%(\mathrm{w} / \mathrm{v})$ bile salt and $100 \mu \mathrm{g} / \mathrm{mL}$ of watersoluble cholesterol. For dead cell assay, the cell pellet was suspended in saline and heat-killed at $121^{\circ} \mathrm{C}$ for 15 min. The dead cells were harvested, after which the pellet was suspended in MRS containing $0.3 \%(\mathrm{w} / \mathrm{v})$ bile salt and $100 \mu \mathrm{g} / \mathrm{mL}$ of water-soluble cholesterol. All strains were incubated at $37{ }^{\circ} \mathrm{C}$ for $24 \mathrm{~h}$, then remaining cholesterol concentration of broth was determined as previously described.

\section{Qualitative determination of bile salts hydrolase (BSH) activity}

BSH activity was determined based on Choi and Chang (2015). Active LAB culture $(10 \mu \mathrm{L})$ was spotted on MRS agar containing $0.5 \%(\mathrm{w} / \mathrm{v})$ taurodeoxycholic acid sodium salt (TDCA) (Sigma, Aldrich) and $0.037 \%(\mathrm{w} / \mathrm{v})$ calcium chloride $\left(\mathrm{CaCl}_{2}\right)$. The agar plates were incubated at $37^{\circ} \mathrm{C}$ for $48 \mathrm{~h}$. The precipitation zone surrounding colonies indicated the presence bile salt hydrolase activity of bacteria.

\section{RESULTS AND DISCUSSION}

\section{Acid tolerance test}

It is well known that probiotic bacteria should be capable of surviving passage through the gastrointestinal tract based on acid tolerance to human gastric juice in the small intestine (Choi and Chang, 2015). In this study, $P$. pentosaceus E5, $P$. pentosaceus E7, $P$. pentosaceus E8 were shown to have more than $85 \%$ of survival rate in MRS broth with $\mathrm{pH} 2$ for $2 \mathrm{~h}$ (Table 1). The results are in accordance with $P$. pentosaceus LJR1, $P$. pentosaceus LJR5, and $P$. pentosaceus LJR9 which have a survival rate of more than $75 \%$ (Ladha and Jeevaratnam, 2018), but in contrast to Osmanagaoglu et al. (2010), who reported $P$. pentosaceus OZF was not resistant to acidic condition. The decrease of the cells number can be associated with the impact of the production of $\mathrm{H}^{+}$ions by acid in the cell wall and metabolism of the isolates, however, acid tolerance was strain dependent (Ayyash et al., 2018).

Table 1: Survival rate (\%) of LAB in MRS broth $\mathrm{pH} 2$ after incubated for $2 \mathrm{~h}$ at $37^{\circ} \mathrm{C}$.

\begin{tabular}{cc}
\hline LAB & Survival rate $(\%)^{*}$ \\
\hline$P$. pentosaceus E5 & $85.21 \pm 0.82$ \\
$P$. pentosaceus E7 & $88.68 \pm 1.58$ \\
$P$. pentosaceus E8 & $90.41 \pm 1.18$ \\
\hline${ }^{*}$ Means of triplicate \pm standard deviation is shown.
\end{tabular}




\section{Bile salt tolerance test}

Tolerance to bile salt was a prerequisite for microbial colonization and metabolic activity in small intestine of the host (Shehata et al., 2016). Pediococcus pentosaceus E5, E7 and E8 strains exhibited good bile salt tolerance with increased in cells number for about 1 log CFU/mL from initial cell number of $7 \log \mathrm{CFU} / \mathrm{mL}$ to $8 \log \mathrm{CFU} / \mathrm{mL}$ (Table 2). Ladha and Jeevaratnam (2018) and Damayanti et al. (2014) reported that $P$. pentosaceus LJR5 and $P$. acidilactici R01, R02 had more than $100 \%$ survival after 2 h incubated in MRS broth with bile salt, in contrast to $P$. ethanolidurans (0\%) (Tokatli et al., 2015). Bile salt can act as antimicrobial agent via disintegration of bacterial membranes. Resistance to bile salt can involves several mechanisms including bile salt efflux, hydrolysis of bile salt, and changes in membrane and cell wall components (Ruiz et al., 2013).

Table 2: Increased in cell number (with initial cell number $7 \log$ CFU $/ \mathrm{mL}$ ) of LAB in MRS broth with $0.3 \%$ bile salt after incubated for $6 \mathrm{~h}$ at $37^{\circ} \mathrm{C}$.

\begin{tabular}{cc}
\hline LAB & $\begin{array}{c}\text { Increased in cell number } \\
(\text { Log CFU/mL) }\end{array}$ \\
\hline P. pentosaceus E5 & $1.05 \pm 0.03$ \\
$P$. pentosaceus E7 & $1.31 \pm 0.03$ \\
P. pentosaceus E8 & $1.04 \pm 0.05$ \\
\hline
\end{tabular}

\section{Antimicrobial activity assays}

Table 3 showed that CFS without neutralization was able to inhibit all pathogenic bacteria with inhibition zone ranging from $2.06 \pm 0.44$ to $5.00 \pm 0.35 \mathrm{~mm}$. Damodharan et al. (2015) reported that $P$. pentosaceus KID7 was able to inhibit Gram positive and Gram negative pathogens with the highest activity against $S$. aureus while Noohi et al. (2016) found that $P$. pentosaceus P3 and P6 had the highest inhibitory activity against $S$. typhimurium. Neutralized CFS of $P$. pentosaceus E7 was unable to inhibit E. coli and S. aureus (Table 3), and this result was contradicting with L. bulgaricus (Georgieva et al., 2015). Overall, CFS without neutralization and neutralized CFS had different antimicrobial activity. CFS was neutralized in order to eliminate putative effect of produced organic acid. The observed inhibition for some strains after elimination of the putative effects of lactic acid raised the question for possible production of other inhibitor substances, such as hydrogen peroxide, bacteriocin and bacteriocin-like substances (Georgieva et al., 2015). Hamida et al. (2015) showed that neutralized CFS of $P$. pentosaceus E5, E7, and E8 lose their inhibitory activity againts Enterococcus casseliflavus after added with proteinase- $\mathrm{K}$, it seems that the antimicrobial compounds are protein such as bacteriocin.

${ }^{*}$ Means of triplicate \pm standard deviation is shown.

Table 3: Antimicrobial activity of LAB against pathogen on MRS agar after incubated for $24 \mathrm{~h}$ at $37^{\circ} \mathrm{C}$.

\begin{tabular}{|c|c|c|c|c|c|c|}
\hline \multirow[t]{2}{*}{$\mathrm{LAB}$} & \multicolumn{3}{|c|}{$\begin{array}{l}\text { Without neutralization CFS } \\
\qquad(\mathrm{pH} \pm 4)\end{array}$} & \multicolumn{3}{|c|}{$\begin{array}{c}\text { Neutralized CFS } \\
(\mathrm{pH} \mathrm{6.5)}\end{array}$} \\
\hline & S. aureus & S.typhimurium & E. coli & S. aureus & S.typhimurium & E. coli \\
\hline P. pentosaceus E5 & ++ & + & ++ & + & + & + \\
\hline P. pentosaceus E7 & ++ & ++ & ++ & - & + & - \\
\hline P. pentosaceus E8 & +++ & ++ & ++ & + & + & - \\
\hline
\end{tabular}

Interpretation of inhibition zone diameter based on Zommiti et al. (2018): (-): no inhibition zone; (+): <3 mm; (++): $3-6$ mm; (+++): > 6 $\mathrm{mm}$.

\section{Autoaggregation and coaggregation ability}

The highest autoaggregation ability (54.85 $\pm 1.03 \%)$ was found in $P$. pentosaceus $\mathrm{E} 7$ after $4 \mathrm{~h}$ and $P$. pentosaceus E8 $(26.97 \pm 0.15 \%)$ after $2 \mathrm{~h}$ of incubation in PBS (Table 4). The autoaggregation ability of $P$. pentosaceus $\mathrm{E} 7$ was better than $P$. pentosaceus A24 (40.4\%) reported by Lee et al. (2014), but lower than P. pentosaceus LJR1 (81\%) (Ladha and Jeevaratnam, 2018) after $4 \mathrm{~h}$ of incubation. According to Wang et al. (2010), strong autoaggregation ability must be higher than $40 \%$ while weak autoaggregation is defined for $10 \%$ or less. In contrast, Rahman et al. (2008) claimed that strong autoaggregation ability is about $70 \%$. Thus, it is difficult to categorize the standard autoaggregation value for Pediococcus sp. (Zommiti et al., 2018).
On the other hand, the strongest coaggregation ability at $2 \mathrm{~h}$ of incubation was found in $P$. pentosaceus $\mathrm{E} 7$ with S. typhimurium, which was $29.73 \%$ (Figure 1 ). The coaggregation ability of $P$. pentosaceus E7 was better than $P$. pentosaceus OZF with $S$. typhimurium (6.26\%) after incubation of $5 \mathrm{~h}$ (Osmanagaoglu et al., 2010). P. pentosaceus E5 with $E$. coli showed the strongest

Table 4: Autoaggregation ability of LAB in PBS after incubated for 2 and $4 \mathrm{~h}$ at $37^{\circ} \mathrm{C}$.

\begin{tabular}{ccc}
\hline \multirow{2}{*}{ LAB } & \multicolumn{2}{c}{ Autoaggregation $(\%)^{*}$} \\
\cline { 2 - 3 } & $2 \mathrm{~h}$ & $4 \mathrm{~h}$ \\
\hline$P$. pentosaceus E5 & $15.46 \pm 3.31$ & $26.58 \pm 2.48$ \\
$P$. pentosaceus E7 & $13.03 \pm 3.98$ & $54.85 \pm 1.03$ \\
P. pentosaceus E8 & $26.97 \pm 0.15$ & $40.88 \pm 2.04$ \\
\hline
\end{tabular}


coaggregation ability (71.01\%) after incubated for $4 \mathrm{~h}$ as similar as reported by Osmanagaoglu et al. (2010). The coaggregation ability is important in inhibiting the growth of pathogens (Ladha and Jeevaratnam, 2018). It has been reported protein, glycoprotein, teichoic acid, and lipoteichoic acid of bacteria cell wall play important role in co- and auto-aggregation of pathogens and LAB (Tuo et al., 2013).

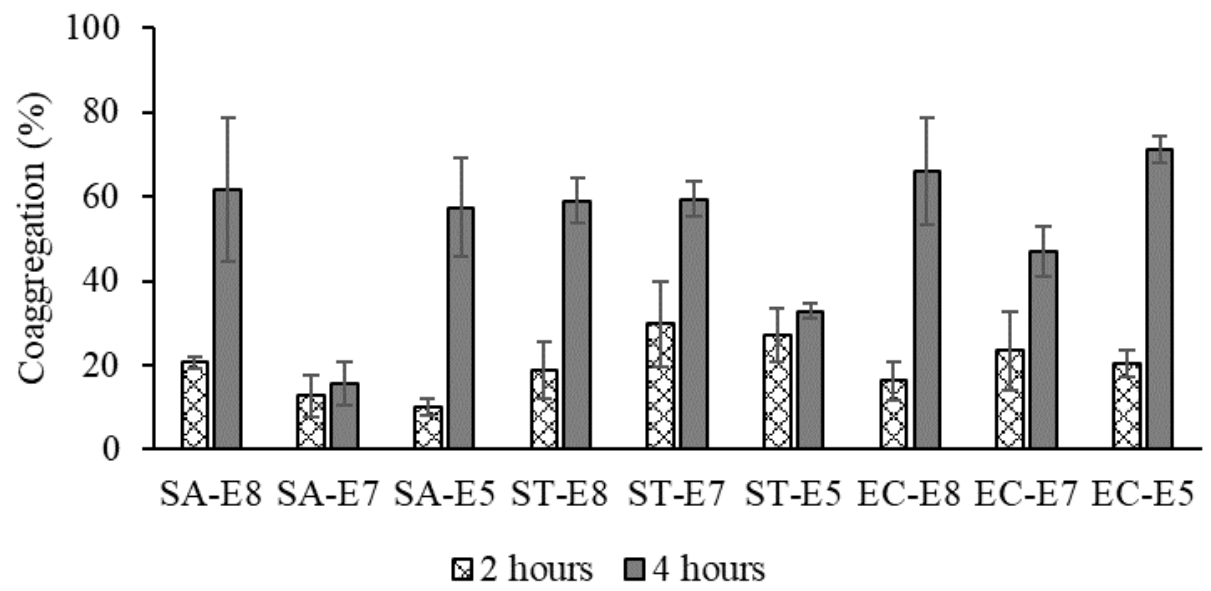

Figure 1: Coaggregation ability of LAB with pathogens in PBS after incubated for 2 and $4 \mathrm{~h}$ at $37^{\circ} \mathrm{C}$. SA: S. aureus; ST: S. typhimurium; EC: E. coli; E5: P. pentosaceus E5; E7: P. pentosaceus E7; E8: P. pentosaceus E8.

\section{Antibiotics susceptibility test}

All $P$. pentosaceus were sensitive to chloramphenicol, but resistant to ampicillin, streptomycin, and kanamycin (Table 5). The result of this study was in accordance with $P$. pentosaceus VJ35 (Vidhyasagar and Jeevaratnam, 2013) and $P$. pentosaceus KID7 (Damodharan et al., 2015) with slight variations. Pediococcus sp. intrinsically is resistant to various groups of antibiotics, including $\beta$ lactams, cephalosporins, aminoglycosides, glycopeptides, streptomycin, kanamycin, tetracycline, and sulfatrimethoprim (Zommiti et al., 2018). When resistance is intrinsic which acquired as the results of chromosomal mutation, probiotic bacteria do not constitute a safety concern because the antibiotic resistance is only passed onto the next generation via the organism's genetic material (Pereira et al., 2018). Antibiotic resistance of probiotics is considered a safety issue when the risk of gene transfers is present (Gueimonde et al., 2013). The transmissible resistance genes are attributed to plasmid containing resistance genes, which may be transferred to intestinal pathogens, and may give rise to negative consequences when humans receive antibiotic therapy. In contrast to intrinsic resistance, it might be considered advantageous, because probiotics with the property of intrinsic resistance could maintain the natural poise of intestinal microbiota (Bacha et al., 2010). Therefore, LAB with intrinsic resistance to antibiotics is generally can be used as a probiotic microorganism (EFSA, 2012).

Table 5: Susceptibility of $L A B$ to antibiotics on MRS agar after incubated for $24 \mathrm{~h}$ at $37^{\circ} \mathrm{C}$.

\begin{tabular}{ccccc}
\hline \multirow{2}{*}{ LAB } & \multicolumn{4}{c}{ Interpretation of LAB to antibiotics* } \\
\cline { 2 - 5 } & \multicolumn{1}{c}{ Chloramphenicol } & Ampicilin & Streptomycin & Kanamycin \\
\hline P. pentosaceus E5 & $\mathrm{S}$ & $\mathrm{R}$ & $\mathrm{R}$ & $\mathrm{R}$ \\
P. pentosaceus E7 & $\mathrm{S}$ & $\mathrm{R}$ & $\mathrm{R}$ & $\mathrm{R}$ \\
P. pentosaceus E8 & $\mathrm{S}$ & $\mathrm{R}$ & $\mathrm{R}$ & $\mathrm{R}$ \\
\hline
\end{tabular}

*Interpretation of inhibition zone diameter was based on Shukla and Goyal (2014): Resistant (R): 0-2 mm; Moderate (M): 3-6 mm; Sensitive(S): 7-13 mm

Cholesterol removal ability by growing, resting, and dead cells

All the tested strains exhibited higher ability to reduce cholesterol than L. rhamnosus R23, the reference strains (Figure 2). Pediococcus pentosaceus E7 had the highest cholesterol removal ability in growing cells (49\%), dead cells $(15 \%)$, and resting cells $(22.2 \%)$. It shows that the cholesterol removal ability of $P$. pentosaceus E7 growing cells was lower than P. pentosaceus VJ56 (63\%) (Vidhyasagar and Jeevaratnam, 2013) and $P$. pentosaceus LAB6 (58\%) (Syakila et al., 2018) but better 
than P. pentosaceus KACC 12311 (28\%) (Damodharan et al., 2015). It has been reported that cholesterol removal by probiotics were strain dependent (Syakila et al., 2018). Growing cells were able to reduce cholesterol from media via incorporation and conversion of cholesterol to coprostanol (Lye et al., 2010).

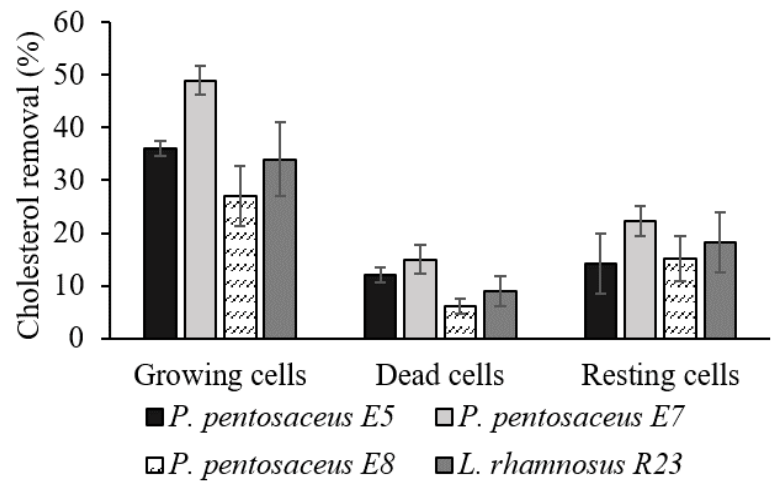

Figure 2: Cholesterol removal (\%) by LAB in MRS broth (for growing and dead cells) and PBS (for resting cells) containing $100 \mu \mathrm{g} / \mathrm{mL}$ cholesterol and $0.3 \%$ bile salt after incubated for $24 \mathrm{~h}$ at $37^{\circ} \mathrm{C}$.

Cholesterol removal by dead cells and resting cells has been reported previously (Vidhyasagar and Jeevaratnam, 2013; Iranmanesh et al., 2014). The ability of dead cells and resting cells to reduce cholesterol was due to binding of cholesterol to the cell membrane (Anila et al., 2016). Iranmanesh et al. (2014) reported that the decrease in cholesterol by dead cells increased with increasing number of cells. Cholesterol binding to $L A B$ varies among strains and species and hypothesized that these differences in binding abilities can be attributed to chemical and structural properties of cell wall peptidoglycans containing amino acids capable of binding to cholesterol (Choi and Chang, 2015). Syakila et al. (2018) showed that cholesterol strongly adhered to cell membranes of $P$. pentosaceus LAB12 as observed by fluorescently tagged cholesterol under a confocal microscope.

\section{Qualitative determination of BSH activity}

In this study, none of the strains were found to be BSH positive and the results was similar to 12 isolates from cheese (Sedlackova et al., 2015) and 5 isolates from food fermentation (Anila et al., 2016). LAB from the gastrointestinal tract are more likely to be $\mathrm{BSH}$ positive, as compared to those without exposures to bile salts (Sedlackova et al., 2015). Miremadi et al. (2014) found that 14 isolates of Lactobacilli and Bifidobacteria from human possesed BSH activity, while Pediococci from fermented vegetables were only $10 \%$ to be $\mathrm{BSH}$ positive (Abriouel et al., 2012). Other findings suggest that BSH activity is influenced by specific substrates, bile salt formed from glycine is more easily hydrolyzed than bile salt from taurine (Hu et al., 2018). A total of 243 isolates tested by $\mathrm{Ru}$ et al. (2018) showed higher BSH activity on the GDCA (glycodeoxycholic acid) substrate (68\%) compared to TDCA (taurodeoxycholic acid) (23\%). Tokatli et al. (2015) stated that the cholesterol-lowering effect of the strains tested is not always related to the ability of deconjugated bile salt such as $P$. pentosaceus VJ31 and VJ35, those which are BSH negative, but able to reduce cholesterol by more than 67\% (Vidhyasagar and Jeevaratnam, 2013). Other mechanisms for cholesterol lowering was conversion of cholesterol to coprostanol (Lye et al., 2010).

\section{CONCLUSION}

In this study, three strains of $P$. pentosaceus have a good probiotic properties (acid tolerance, bile salt tolerance, antimicrobial activity, autoaggregation and coaggregation ability, and antibiotics susceptibility) and cholesterollowering ability. Although they are $\mathrm{BSH}$ negative, $P$. pentosaceus E7 showed the highest cholesterol-lowering ability. This strains could be potentially used in the development of probiotic product with their functional properties in cholesterol-lowering effect. Based on the finding from this study, further in vitro studies are needed to determine the mechanism involved in the reduction of cholesterol and in vivo study is necessary to prove the hypercholesterolemic effect.

\section{ACKNOWLEDGEMENTS}

This research was funded by the Master Thesis Research Grant (4395/IT3.L1/PN/2019) from the Indonesian Ministry of Research, Technology and Higher Education to Anja Meryandini.

\section{REFERENCES}

Abriouel, H., Benomar, N., Cobo, A., Caballero, N., Fernandez, M. A., Perez-Pulido, R. and Galvez, A. (2012). Characterization of lactic acid bacteria from naturally-fermented Manzanilla Alorena green table olives. Food Microbiology Journal 32(2), 308-316.

Alba, M. M. J., Rodriguez, J. A. P., Lomeli, M. L. C. and Martinez, B. E. G. (2018). Cholesterol assimilation, acid and bile survival of probiotic bacteria isolated from food and reference strains. CyTA-Journal of Food 16(1), 36-41.

Anila, K., Kunzes, A. and Bhalla, T. C. (2016). In vitro cholesterol assimilation and functional enzymatic activities of putative probiotic Lactobacillus sp. isolated from fermented foods/beverages of North West India. Nutrition and Food Sciences 6(2), 1-5.

Ayyash, M., Abushelaibi, A., Al-Mahadin, S., Enan, M., El-Tarabily, K. and Shah, N. (2018). In-vitro investigation into probiotic characterisation of Streptococcus and Enterococcus isolated from camel milk. LWT - Food Science and Technology 87, 478487. 
Bacha, K., Mehari, T. and Ashenafi, M. (2010). Antimicrobial susceptibility patterns of lab isolated from Wakalim, a traditional ethiopian fermented sausage. Journal of Food Safety 30(1), 213-223.

Choi, E. A. and Chang, H. C. (2015). Cholesterollowering effects of a putative probiotic strain Lactobacillus plantarum EM isolated from kimchi. LWT-Food Science and Technology 62(1), 210-217.

Damayanti, E., Julendra, H., Sofyan, A. and Hayati, S. N. (2014). Bile salt and acid tolerant of lactic acid bacteria isolated from proventriculus of broiler chicken. Media Peternakan 37(2), 80-86.

Damodharan, K., Lee, Y. S., Palaniyandi, S. A., Yang, S. H. and Suh, J. W. (2015). Preliminary probiotic and technological characterization of Pediococcus pentosaceus strain KID7 and in vivo assessment of its cholesterol-lowering activity. Frontiers in Microbiology 6, 768-782.

[EFSA]. European Food Safety Authority. (2012). Guidance on the assessment of bacterial susceptibility to antimicrobials of human and veterinary importance. EFSA Journal 10, 27-40.

Georgieva, R., Yocheva, L., Tserovska, L., Zhelezova, G., Stefanova, N., Atanasova, A., Danguleva, A., Ivanova, G., Karapetkov, N., Rumyan, N. and Karaivanova, E. (2015). Antimicrobial activity and antibiotic susceptibility of Lactobacillus and Bifidobacterium spp. intended for use as starter and probiotic cultures. Biotechnology \& Biotechnological Equipment 29(1), 84-91.

Gueimonde, M., Sanchez, B., Reyes-Gavilan, C. G. and Margollez, A. (2013). Antibiotic resistance in probiotic bacteria. Frontiers in Microbiology 4, 202-208.

Hamida, F., Wiryawan, K. G. and Meryandini, A. (2015). Selection of lactic acid bacteria as probiotic candidate for chicken. Media Peternakan 38(2), 138-144.

Hu, P. L., Yuan, Y. H., Yue, T. L. and Guo, C. F. (2018). A new method for the in vitro determination of the bile tolerance of potentially probiotic lactobacilli. Applied Microbiology and Biotechnology 102(4), 1903-1910.

llavenil, S., Vijayakumar, M., Kim, D. H., Valan, A. M., Park, H. S. and Ravikumar, S. (2016). Assessment of probiotic, antifungal and cholesterol lowering properties of Pediococcus pentosaceus KCC-23 isolated from Italian ryegrass. Journal of the Science of Food and Agricultural 96, 593-601.

Iranmanesh, M., Ezzatpanah, $\mathbf{H}$. and Mojgani, N. (2014). Antibacterial activity and cholesterol assimilation of lactic acid bacteria isolated from traditional Iranian dairy products. LWT-Food Science and Technology 58(2), 355-359.

Ladha, G. and Jeevaratnam, K. (2018). Probiotic potential of Pediococcus pentosaceus LJR1, a bacteriocinogenic strain isolated from rumen liquor of goat (Capra aegagrus hircus). Food Biotechnology 32(1), 60-77.

Lee, K. W., Park, J. Y., Sa, H. D., Jeong, J. H., Jin, D. E., Heo, H. J. and Kim, J. H. (2014). Probiotic properties of Pediococcus strains isolated from jeotgals, salted and fermented Korean seafood. Anaerobe 28, 199-206.

Lee, K. W., Shim, J. M., Park, S. K., Heo, H. J., Kim, H. J., Ham, K. S. and Kim, J. H. (2016). Isolation of lactic acid bacteria with probiotic potentials from kimchi, traditional Korean fermented vegetable. LWTFood Science and Technology 71, 130-137.

Lye, H. S., Rusul, G. and Liong, M. T. (2010). Removal of cholesterol by Lactobacilli via incorporation of and conversion to coprostanol. Journal of Dairy Science 93, 1383-1392.

Manini, F., Casiraghi, M. C., Poutanen, K., Brasca, M., Erba, D. and Plumed-Ferrer, C. (2016). Characterization of lactic acid bacteria isolated from wheat bran sourdough. LWT-Food Science and Technology 66, 275-283.

Miremadi, F., Ayyash, M., Sherkat, F. and Stojanovska, L. (2014). Cholesterol reduction mechanisms and fatty acid composition of cellular membranes of probiotic Lactobacilli and Bifidobacteria. Journal of Functional Foods 9, 295-305.

Noohi, N., Ebrahimipour, G., Rohani, M., Talebi, M. and Pourshafie, M. R. (2016). Evaluation of potential probiotic characteristics and antibacterial effects of strains of Pediococcus species isolated from broiler chickens. British Poultry Science 57(3), 317-323.

Nuraida, L., Winarti, S., Hana and Prangdimurti, E. (2011). Evaluasi in vitro terhadap kemampuan isolat bakteri asam laktat asal air susu ibu untuk mengasimilasi kolesterol dan mendekonjugasi garam empedu. Jurnal Teknologi dan Industri Pangan 12(1), 46-52.

Ooi, L. G. and Liong, M. T. (2010). Cholesterol-lowering effects of probiotics and prebiotics: A review of in vivo and in vitro findings. International Journal of Molecular Science 11, 2499-2522.

Osmanagaoglu, O., Kiran, F. and Ataoglu, H. (2010). Evaluation of in vitro probiotic potential of Pediococcus pentosaceus OZF isolated from human breast milk. Probiotics and Antimicrobial Proteins 2, 162-174.

Pereira, G. V. D. M., Coelho, B. D. C., Junior, A. I. M., Thomaz-Soccol, V. and Soccol, C. R. (2018). How to select a probiotic? A review and update of methods and criteria. Biotechnology Advance Journal 36(8), 2060-2076.

Rahman, M. M, Kim, W. S., Kumura, H. and Shimazaki, K. (2008). Autoaggregation and surface hydrophobicity of bifidobacteria. World Journal of Microbiology and Biotechnology 24, 1593-1598.

Ramkumar, S., Raghunath, A. and Raghunath, S. (2016). Statin therapy: Review of safety and potential side effects. Acta Cardiologica Sinica 32, 631-639.

Ru, X., Zhang, C. C., Yuan, Y. H., Yue, T. L. and Guo, C. F. (2018). Bile salt hydrolase activity is present in nonintestinal lactic acid bacteria at an intermediate level. Applied Microbiology and Cell Biotechnology 103(2), 893-902.

Ruiz, L., Margolles, A. and Sanchez B. (2013). Bile resistance mechanisms in Lactobacillus and Bifidobacterium. Frontiers in Microbiology 4, 396-404. 
Seddik, H. A, Bendali, F., Cudennec, B. and Drider, D. (2017). Anti-pathogenic and probiotic attributes of Lactobacillus salivarius and Lactobacillus plantarum strains isolated from feces of Algerian infants and adults. Research in Microbiology 168(3), 244-254.

Sedlackova, P., Horackova, S., Shi, T., Kosova, M. and Plockova, M. (2015). Two different methods for screening of bile salt hydrolase activity in Lactobacillus strains. Czech Journal of Food Sciences 33(1), 13-18.

Shehata, M. G., El-Sohaimy, S. A., El-Sahn, M. A. and Youssef, M. M. (2016). Screening of isolated potential probiotic lactic acid bacteria for cholesterol lowering property and bile salt hydrolase activity. Annals of Agricultural Science 61(1), 65-75.

Shukla, R. and Goyal, A. (2014). Probiotic potential of Pediococcus pentosaceus CRAG3: A new isolate from fermented cucumber. Probiotics and Antimicrobial Protein 6(1), 11-21.

Syakila, R. N., Lim, S. M., Kustrin, S. A., Lim , F. T. and Ramasamy, K. (2018). In vitro assessment of pediococci- and lactobacilli-induced cholesterollowering effect using digitally enhanced highperformance thin-layer chromatography and confocal microscopy. Analytical and Bioanalytical Chemistry 411(6), 1181-1192.

Tok, E. and Aslim, B. (2010). Cholesterol removal by some lactic acid bacteria that can be used as probiotic. Microbiology and Immunology 54, 257-264.

Tokatli, M., Gulgor, G., Elmaci, S. B., Isleyen, N. A. and Ozcelik, F. (2015). In vitro properties of potential probiotic indigenous lactic acid bacteria originating from traditional pickles. Biomed Research International 2015, 1-8.

Tuo, Y., Yu, H., Ai, L., Wu, Z., Guo, B. and Chen, W. (2013). Aggregation and adhesion properties of 22 Lactobacillus strains. Journal of Dairy Science 96, 4252-4257.

Vidhyasagar, V. and Jeevaratnam, K. (2013). Evaluation of Pediococcus pentosaceus strains isolated from ldly batter for probiotic properties in vitro. Journal of Functional Foods 5, 235-243.

Wang, L. Q., Meng, X. C., Zhang, B. R., Wang, Y. and Shang, Y. L. (2010). Influence of cell surface properties on adhesion ability of bifidobacteria. World Journal of Microbiology and Biotechnology 26, 19992007.

Wang, J., Li, B., Zhou, L., Zhang, X. and Shi, P. (2016). Probiotic potential and function of a Lactobacillus strain L1 isolated from silage. Journal of Food Safety 37(4), 1-10.

Zommiti, M., Bouffartigues, E., Maillot, O., Barreau, M., Szunerits, S., Sebei, K., Feuilloley, M., Connil, N. and Ferchichi, M. (2018). In vitro assessment of the probiotic properties and bacteriocinogenic potential of Pediococcus pentosaceus MZF16 isolated from artisanal tunisian meat "dried ossban". Frontiers in Microbiology 9, 1-15. 